\title{
Rates of Incidental Thyroid Nodule and Thyroid Cancer Detection in Routine Check-up Examinations: A Single-center Study
}

\author{
Rutin Check-up Muayenesi ile İnsidental Tiroid Nodulü ve Tiroid \\ Kanseri Saptanma Oranı: Tek Merkezli Çalışma
}

\section{Derya Arğun1, (D) Pelin Basım²}

1İstanbul Aydın University Medical Faculty, Department of Internal Medicine, İstanbul, Turkey

2İstanbul Medipol University Medical Faculty, Department of General Surgery, İstanbul, Turkey

\section{Abstract}

Objective: Check-up examinations have gained importance in the last decade and become a common reason for people to refer to healthcare institutions to seek medical help. Thyroid nodules are frequently detected during check-up examinations. This study aimed to determine the frequency of thyroid nodules and the rate of thyroid cancer development in patients presenting for a check-up and to define the role of variables in thyroid cancer detection.

Method: The computer database of the patients, who applied for a checkup examination, was systematically screened, and the records of thyroid ultrasonography (US) were accessed. Patients with any known history of thyroid disease or thyroid cancer and those using medication for an existing thyroid disease were excluded. The demographic data, thyroid US reports, cytology and histopathology results, and free t3 (fT3), free t4 (fT4), and thyroid-stimulating hormone (TSH) levels were evaluated and recorded. Body mass index (BMI) was calculated. Data were analyzed using SPSS v. 25.

Results: Of the 30,449 check-up patients, 24,362 were evaluated. Incidental thyroid nodules were detected in 5.645 (23.17\%) patients. The mean BMI of these patients was $56 \pm 2.01 \mathrm{~kg} / \mathrm{m}^{2}$, and their mean $\mathrm{TSH}$, fT3 and fT4 values were $2.87 \pm 0.45 \mathrm{mlU} / \mathrm{mL}, 3.76 \pm 0.87 \mathrm{pg} / \mathrm{mL}$ and $1.23 \pm 0.24 \mathrm{pg} / \mathrm{mL}$, respectively. The mean nodule size was $1.31 \pm 0.56$ $\mathrm{mm}$. While 2.936 (52.01\%) of the nodules were solid, 1.377 (24.39\%) were cystic and 1.332 (23.59\%) were mixed. Of all the nodules, 1.916 (33.94\%) were in the TIRADS 2 category, $3.273(57.98 \%)$ in the TIRADS 3 category, $234(4.31 \%)$ in the TIRADS 4a category, $114(1.27 \%)$ in the TIRADS $4 \mathrm{~b}$ category, $72(1.27 \%)$ in the TIRADS 4c category, and $36(0.63 \%)$ in the TIRADS 5 category. For 392 patients that underwent a biopsy, the

\section{Öz}

\begin{abstract}
Amaç: Check-up muayeneleri son on yılda önem kazanmış ve tıbbi yardım isteme amaçlı sağlık kurumlarına başvuruların en yaygın nedenleri arasında yerini almıştır. Tiroid nodülleri, check-up muayenesi sırasında sıkıkla tespit edilmektedir. Çalışmamızın amacı, check-up muayenesine başvuran bireylerde tiroid nodülü sıklığını ve tiroid kanseri gelişme oranını belirlemek ve tiroid kanseri saptanmasında değişkenlerin rolünü tanımlamaktır
\end{abstract}

Yöntem: Check-up muayenesi için başvuran hastaların bilgisayar database kayıtları sistematik biçimde taranarak, tiroid ultrasonografisi (USG) yapılan hasta kayıtlarına erişildi. Öncesinde bilinen herhangi bir tiroid hastalığı veya tiroid kanseri öyküsü olan ve mevcut bir tiroid hastalığı için ilaç kullanan hastalar çalışma dışı bırakıldı. Hasta grubunun demografik bilgileri, tiroid USG raporları, sitoloji ve histopatoloji sonuçlar ile serbest T3 (sT3), serbest T4 (sT4) ve tiroid stimulan hormon (TSH) düzeyleri değerlendirilerek kaydedildi. Vücut kitle indeksleri (VKi) hesaplandı. Veriler, SPSS 25 istatistik paket programı ile analiz edildi.

Bulgular: Otuz bin dört yüz kırk dokuz check-up hastasının 24.362'si değerlendirildi. Beş bin altı yüz kırk beş $(\% 23,17)$ hastada insidental tiroid nodülü saptandı. Bu hastaların ortalama VKI'si $56 \pm 2,01 \mathrm{~kg} / \mathrm{m}^{2}$, TSH değeri $2,87 \pm 0,45 \mathrm{mlU} / \mathrm{mL}$, sT3 değeri 3,76 $\pm 0,87 \mathrm{pg} / \mathrm{mL}$ ve sT4 değeri 1,23 $\pm 0,24$ $\mathrm{pg} / \mathrm{mL}$ idi. Ortalama nodül boyutu 1,31 $\pm 0,56 \mathrm{~mm}$ iken, nodüllerin 2,936's (\%52,01) solid nodül, 1,377'si (\%24,39) kistik nodül, 1,332'si (\%23,59) mikst nodül olarak gözlendi. Nodüllerin 1,916'sı (\%33,94) TIRADS 2, 3,273'ü (\%57,98) TIRADS 3,234'ü $(\% 4,31)$ TIRADS 4a, 114'ü $(\% 1,27)$ TIRADS 4b, 72 'si $(\% 1,27)$ TIRADS 4c ve 36's $(\% 0,63)$ TIRADS 5 kategorisindeydi. Biyopsi yapılan 392 hastanın 224'ünün (\%57,14) sonucu benign, 100'ünün $(\% 25,51)$ şüpheli malign ve $68^{\prime}$ inin $(\% 17,34)$ malign olarak raporlandı.

Address for Correspondence: Derya Arğun, İstanbul Aydın University Medical Faculty, Department of Internal Medicine, İstanbul, Turkey E-mail: dr.deryaargun@gmail.com ORCID: orcid.org/0000-0002-0141-3515 Received: 05.12.2020 Accepted: 18.06.2021

Cite this article as: Arğun D, Basım P. Rates of Incidental Thyroid Nodule and Thyroid Cancer Detection in Routine Check-up Examinations: A Singlecenter Study. Bagcilar Med Bull 2021;6(3):248-256

${ }^{\circ}$ Copyright 2021 by the Health Sciences University Turkey, Bagcilar Training and Research Hospital Bagcilar Medical Bulletin published by Galenos Publishing House. 


\section{Abstract}

results were reported as benign for 224 (57.14\%), suspected malignancy for 100 (25.51\%), and malignant for 68 (17.34\%). The rates of patients diagnosed with papillary, follicular and medullary thyroid cancers were $63.15 \%, 34.21 \%$ and $2.63 \%$, respectively. When the multinominal logistic regression analysis was applied to all significant variables in the univariate analysis, the risk of thyroid cancer was increased 1.7-fold by increased $\mathrm{BMI}$ [odds ratio (OR): 1.71, 95\% confidence interval (Cl): 1.43-2.96], 1.8fold by female gender [OR: 1.79, (CI): 1.21-2.67], 1.6-fold by solid structure nodule type [OR: 1.62, (Cl): 1.27-3.54], 2.7-fold by increased nodule size [OR: 2.71, (Cl): 1.11-3.31], and 4.7-fold by increased TIRADS [OR: 4.73, (CI): 1.76-7.31].

Conclusion: The main difficulty in evaluating and managing thyroid nodules is to avoid the inappropriate overuse of thyroid US, thyroid biopsy, and surgery while trying to identify clinically significant malignant nodules. Concerning the diagnosis of thyroid cancer through a checkup examination, the data obtained as a result of more detailed studies should be evaluated, and it should be kept in mind that the increase in the incidence of thyroid cancer in the last three decades may be due to not only overdiagnosis but also a real increase in incidence. However, considering that early diagnosis of thyroid cancer without lymph node involvement can reduce both surgical complications and prevent the risks of radioactive iodine treatment, it is concluded that thyroid cancer being detected at an early stage constitutes an important advantage for the healthy population undergoing a check-up.

Keywords: Check-up examination, thyroid cancer, thyroid nodule

\section{Öz}

Papiller tiroid kanseri tanısı konulan hastaların oranı \%63,15, foliküler tiroid kanseri \%34,21 ve medüller tiroid kanseri \%2,63 olarak tespit edildi. Univariate analizlerde anlamlı bulunan tüm değişkenlere multinominal lojistik regresyon analizi uygulandığında artan VKI'nin 1,7 kat [olasılık oranı (OO): 1,71, \%95 güven aralığı (GA): 1,43-2,96], kadın cinsiyetin 1,8 kat [OO: 1,79, (GA): 1,21-2,67], solid nodül yapısının 1,6 kat [OO: 1,62, (GA): 1,27-3,54], artan nodül çapının 2,7 kat [OO: 2,71, (GA): 1,11-3,31], ve artan TIRADS skorunun 4,7 kat [OO: 4,73, (GA): 1,76-7,31] tiroid kanseri gelişimini artırıcı etkisi olduğu tespit edildi.

Sonuç: Tiroid nodüllerini değerlendirme ve yönetmedeki ana zorluk bir yandan tiroid US, tiroid biyopsisi ve cerrahinin uygunsuz aşırı kullanımından kaçınırken, diğer yandan klinik olarak önemli malign olanları tanımlamaya çalışmaktır. Check-up muayenesi ile tiroid kanseri tanısı koyma ile ilgili olarak, daha ayrıntılı çalışmaların sonucunda elde edilen veriler değerlendirilmeli ve son otuz yılda tiroid kanseri insidansının artmasının sadece aşıı tanıdan değil, gerçek bir insidans artışından kaynaklanabileceği akılda tutulmalıdır. Öte yandan lenf nodu tutulumsuz erken tanı tiroid kanseri ile hem cerrahi komplikasyonların azaltılabileceği hem de radyoaktif iyot tedavisinin risklerinden korunabileceği göz önünde bulundurulduğunda, evrece erken yakalanmış tiroid kanserlerinin, checkup amacıyla başvuran sağlıklı popülasyon için önemli bir avantaj olduğu kanısına varılmıştır.

Anahtar kelimeler: Check-up muayenesi, tiroid kanseri, tiroid nodülü

\section{Introduction}

Check-up examinations have gained importance in the last decade and are now among the most common reasons for adults to present to healthcare institutions (1). In the literature, a check-up examination, which is also referred to as a physical or preventive health examination, is defined as seeking health care motivated by the need for general health assessment, and the purpose of this examination is to define risk factors and early signs of disease, as well as preventing future diseases through early interventions (2). The main goal of this early evaluation program is to manage diseases that are usually diagnosed late since they show less symptoms in the progression process. Routine medical check-ups include blood tests, liver and kidney function tests, electrocardiogram, echocardiogram, abdominal ultrasound (US), and thyroid US. Although routine control has little value in identifying acute diseases, a growing body of evidence shows the effects of early diagnosis on certain diseases, such as diabetes, cardiovascular disorders, liver dysfunction, gynecological diseases, and malignancy (3). However, the views and information presented in the literature differ concerning whether a routine control can benefit patients' prognosis and have an impact on the final prognosis or have equal value for different diseases, and no specific consensus-based algorithm has yet been established. Therefore, it is important to estimate the value of check-up examinations in the early detection of specific diseases and improving clinical outcomes.

Thyroid nodules are a common clinical problem mostly detected incidentally in all populations. Epidemiological studies have shown that the prevalence of palpable thyroid nodules in iodine-sufficient regions of the world is approximately $5 \%$ in women and $1 \%$ in men (4). However, with the introduction of high-resolution US into clinical practice, the rate of thyroid nodule detection in randomly selected individuals has increased to $19-68 \%$ (5). The clinical significance of thyroid nodules is based on the need to exclude thyroid cancer seen in $7-15 \%$ of cases depending on age, gender, radiation exposure history, family history, and other factors (6). In the United States, it is estimated that around 53,000 new cases of thyroid cancer will be diagnosed in 2020, compared to 37,200 in 2009 (7). This annual incidence has almost tripled from 4.9 per 100,000 in 1975 to 14.3 per 100,000 in 2009 , and this significant increase in the rate of cancer development from nodules places a greater responsibility on physicians in the process of excluding a cancer diagnosis (8). This change in detection rates has been mostly attributed to an increased 
incidence of papillary thyroid cancer (PTC). Furthermore, while only $25 \%$ of new thyroid cancers diagnosed in 1988 1989 were $1 \mathrm{~cm}$, this rate increased to $39 \%$ in new thyroid cancer diagnoses in 2008-2009 (8). This change over the years is considered to be due to the increased use of thyroid US or other imaging modalities, and early diagnosis and treatment (9). In a population-based study, it was reported that the incidence of thyroid cancer doubled from 2000 to 2012 compared to the previous decade, and this situation could also be associated with clinically occult cancers being detected incidentally on imaging or pathological analyses (10).

Thyroid nodules are frequently detected in patients being evaluated for other medical conditions with no thyroidrelated symptoms or undergoing a routine check-up examination (5). Thyroid US provides the opportunity to evaluate the size and location of nodules, their benign or suspicious characters, nodule composition, and presence of cervical lymph nodes. The evaluation of a thyroid nodule on US is valuable in terms of providing information on the localization of the nodule in the gland, its size (threedimensional), its echo structure (solid, cystic, complex), shape, imaging features (echogenicity, calcifications, margin pattern, presence of halo, blood flow, and extrathyroidal spread) and presence of lymphadenopathy (11). During a check-up examination, the US features of a nodule that may increase the risk of cancer should be evaluated. The main reason for evaluating nodules with US is to investigate features that may predict malignancy risk. It is known that the malignancy risk of a nodule increases in the presence of certain US features. In US, a nodule being hypoechogenic compared to normal thyroid parenchyma, irregular and indeterminate infiltrative borders, presence of microcalcification(s), absence of halo, height of the nodule being greater than its transverse dimension, and increased intranodular blood supply increase the risk of malignancy. In addition, the characteristic appearance of some types of cancer can also be guiding. For example, PTC is usually solid or predominantly solid and hypoechoic, and it often presents with infiltrative irregular borders and microcalcification. In contrast, follicular thyroid carcinoma (FTC) is generally isoechoic and rarely hyperechoic; it is thick and presents with an irregular halo but not microcalcification.

In the detection of nodules, it is vital to make a benign and malignant differentiation. A thyroid fine-needle aspiration biopsy (FNAB) is the most convenient, inexpensive and reliable method to reveal this situation and is the gold standard test in distinguishing benign and malignant thyroid nodules (12). The indication for a thyroid FNAB is basically determined by staging based on the size and US features of the nodule. When a thyroid biopsy is performed, the next management step (follow-up or surgery) of the nodule depends on the outcome of the biopsy, molecular markers and/or repeat thyroid FNAB, as well as the individual preferences of the patient (13).

An average of $5 \%$ of all thyroid nodules are cancerous and the clinical presentation finding of thyroid cancers is usually in the form of a palpable or incidentally detected thyroid nodule (4). An early and accurate diagnosis is vital for people with thyroid cancer, as in the case of other cancer types. Although thyroid cancer is known to have the best cure and long survival rates and generally well-differentiated histological features compared to other cancers, its early diagnosis is still crucial since it significantly reduces distant metastasis and mortality rates in individuals (14).

Due to the localization of the thyroid gland, it is easy to diagnose thyroid nodules and a possible thyroid cancer early with US and thyroid FNAB. For this reason, a routine check-up examination can be considered as the most effective way to detect thyroid cancer at an early stage. The aim of our study is to determine the frequency of thyroid nodules, the rate of thyroid cancer development, and their relationship with the variables in individuals without any known thyroid disease, who presented to our hospital for a check-up examination for general health evaluation.

\section{Materials and Methods}

The study was approved by the Ethics Committee of Medipol University (10840098-604.01.01-E.17833 number: 535) and conducted in accordance with the principles of the Declaration of Helsinki. The computer database records of the patients who presented to Medipol Mega University Hospital for a routine check-up examination between 2015 and 2020 were screened. The hospital's database was systematically screened, and after accessing the thyroid US records, the demographic data of the patients, thyroid US reports, cytology and histopathology results, free t3 (fT3), free t4 (fT4) and thyroid-stimulating hormone (TSH) levels were evaluated and recorded. Body mass index (BMI) was calculated by dividing the body weight by the square of the height $\left(\mathrm{kg} / \mathrm{m}^{2}\right)$ and recorded.

The US evaluation was performed using three separate Logic P5 devices and a 10-12 $\mathrm{mHz}$ probe available in the hospital. The US characteristics were evaluated in three categories: 
the presence of nodule (yes, no), nodule composition (solid, cystic, and mixed), and nodule diameter (mm). In addition, the nodules were scored according to the thyroid imaging reporting and data system (TIRADS) classification, which is a scoring system based on the evaluation of the composition of the nodule and its microcalcifications, echogenicity, shape, margin structure, and the presence of bright foci. Accordingly, the nodules were categorized as TIRADS 1 (normal thyroid gland), 2 (benign lesions), 3 (possible benign lesions), 4a (one suspicious feature), 4b (two suspicious features), 4c (three to four suspicious features) and 5 (all five suspicious traits). The presence of solid components, significant hypoechogenicity, microlobulation, microcalcification, and an increased vertical-horizontal height ratio were considered as suspicious features. In the presence of multiple nodules, the nodule with the highest TIRADS score was taken into consideration irrespective of size.

As a result of the evaluated data, the patients who were considered to be suitable for thyroid FNAB were determined. The cytology results were evaluated in three categories: benign, suspicious for malignancy, and malignant. The operation types of the surgical patients were recorded. All patients who were recommended a surgical operation but were not operated in our hospital were contacted by telephone to confirm that they had not undergone any thyroid operation or follow-up of nodules prior to the study date. Patients with a prior history of any known thyroid disease or thyroid cancer and those using any medication for an existing thyroid disease were excluded. The histopathology results were classified as benign, PTC, FTC, and medullary thyroid carcinoma (MTC).

\section{Statistical Analysis}

In the study, the data collected from the hospital database were analyzed using SPSS v. 25. All the data belonging to the study showed normal distribution according to the Kolmogorov-Smirnoff test. Thyroid cancer detection rates and related factors were investigated using the Student's t-test (continuous variables) and the chisquare test (categorical variables). A p-value of less than 0.05 was considered statistically significant. Variables found significant in the Student's t-test were analyzed with decision groups. Possible factors determined as a result of one-way analysis were further analyzed with a multinominal logistic regression analysis to identify the independent predictors of the disease. The variables with a confidence interval (CI) of $95 \%$ and an odds ratio (OR) of $>1$ were accepted to indicate an increased risk of detecting thyroid cancer in existing nodules.

\section{Results}

A total of 30,449 patients, including 12,207 (40.09\%) male and $18,242(59.91 \%)$ female, were determined to have applied to the hospital for check-up purposes. The mean age of all these patients was $39.3 \pm 2.2$ years. Table 1 shows the general characteristics of the check-up patients. The mean BMI was $25.12 \pm 3.76 \mathrm{~kg} / \mathrm{m}^{2}$, and the mean TSH, fT3 and fT4 values were $2.15 \pm 0.62 \mathrm{mIU} / \mathrm{mL}, 3.88 \pm 0.69 \mathrm{pg} /$ $\mathrm{mL}$, and $1.38 \pm 0.33 \mathrm{pg} / \mathrm{mL}$, respectively. A total of 6,087 patients with a previously known thyroid disease [followed up thyroid nodules, 1,216 (3.99\%); hypothyroidism, 4,683 (15.38\%); and hyperthyroidism, 188 (0.63\%)] were excluded from the study.

Thyroid nodules were incidentally detected in 5,645 of the 24,362 patients who were evaluated. Based on this number, it was determined that $23.17 \%$ of all check-up patients had thyroid nodules. The characteristics of the patients with incidentally detected thyroid nodules are shown in Table 2. While 3,014 (53.39\%) of these patients were female, $2,631(46.61 \%)$ were male. The patients with thyroid nodules had a mean BMI of $27.56 \pm 2.01 \mathrm{~kg} / \mathrm{m}^{2}$, a mean TSH value of $2.87 \pm 0.45 \mathrm{mIU} / \mathrm{mL}$, a mean fT3 value of $3.76 \pm 0.87 \mathrm{pg} / \mathrm{mL}$, and a mean fT 4 value of $1.23 \pm 0.24 \mathrm{pg} / \mathrm{mL}$. The mean nodule size was $1.31 \pm 0.56 \mathrm{~mm}$, and 2,936 (52.01\%) of the detected nodules were solid, 1,377 (24.39\%) were cystic, and 1,332 (23.59\%) were mixed. When the nodules were categorized according to the TIRADS classification in US imaging, 1,916 (33.94\%) were evaluated as TIRADS 2, 3,273 (57.98\%) as TIRADS 3, $234(4.31 \%)$ as TIRADS $4 \mathrm{a}, 114(1.27 \%)$ as TIRADS 4b, $72(1.27 \%)$ as TIRADS $4 \mathrm{c}$, and $36(0.63 \%)$ as TIRADS 5.

\section{Table 1. Characteristics of the check-up patients}

\begin{tabular}{|c|c|}
\hline Variable & \\
\hline Age (mean $\pm \mathrm{SD}$ ) & $39.3 \pm 2.2$ years \\
\hline \multicolumn{2}{|l|}{ Gender $(n=30.449) / \%$} \\
\hline Male & $12,207(40.09 \%)$ \\
\hline Female & $18,242(59.91 \%)$ \\
\hline Body mass index $\left(\mathrm{kg} / \mathrm{m}^{2}\right)$ & $25.12 \pm 3.76$ \\
\hline $\mathrm{TSH}$ value (mean $\pm \mathrm{SD}$ ) $\mathrm{mIU} / \mathrm{L}$ & $2.15 \pm 0.62$ \\
\hline Free $\mathrm{T} 3$ value (mean $\pm \mathrm{SD}$ ) $\mathrm{pg} / \mathrm{mL}$ & $3.88 \pm 0.69$ \\
\hline Free T4 value (mean $\pm \mathrm{SD}$ ) $\mathrm{pg} / \mathrm{mL}$ & $1.38 \pm 0.33$ \\
\hline \multicolumn{2}{|l|}{ Known thyroid disease } \\
\hline None & $24,362(80.00 \%)$ \\
\hline Followed up thyroid nodule & $1,216(3.99 \%)$ \\
\hline Hypothyroidism & $4,683(15.38 \%)$ \\
\hline Hyperthyroidism & $188(0.63 \%)$ \\
\hline
\end{tabular}

TSH: Thyroid-stimulating hormone, SD: Standard deviation 
Since 122 of 514 patients who were recommended a biopsy did not undergo this procedure in our hospital, the results of the remaining 392 patients were evaluated. Table 3 demonstrates the characteristics of the patients who underwent a biopsy. The biopsy results were reported as benign for $224(57.14 \%)$ patients, suspected malignancy for 100 (25.51\%), and malignant for 68 $(17.34 \%)$. Thyroid surgery was performed in 142 of 168 patients, who were recommended to undergo an operation, in our hospital. The surgical procedures performed in these patients were lobectomy in 36 patients (25.35\%), bilateral total thyroidectomy in 96 $(67.60 \%)$, and bilateral total thyroidectomy + central neck dissection in 10 (7.04\%). According to the final pathology report of 142 operated patients, there were malignant thyroid tumors in 114 patients $(80.28 \%)$, of whom $40.35 \%$ were male and $59.65 \%$ were female. The rates of patients diagnosed with PTC, FTC and MTC were $63.15 \%, 34.21 \%$, and $2.63 \%$, respectively. Eight patients (7.01\%) had lymph node metastasis. Radioactive iodine

Table 2. Characteristics of the patients with thyroid nodules incidentally detected during the check-up examination

\begin{tabular}{ll} 
Variable & \\
\hline Thyroid nodule presence $(\mathbf{n = 2 4 , 3 6 2}) / \%$ & \\
Absent & $18,717(76.82 \%)$ \\
Present & $5,645(23.18 \%)$ \\
Gender in nodule presence $(\mathbf{n = 5 . 6 4 5 ) / \%}$ & \\
Male & $2,631(46.61 \%)$ \\
Female & $3,014(53.39 \%)$ \\
BMI in nodule presence $\left(\mathrm{kg} / \mathrm{m}^{2}\right)$ & $27.56 \pm 2.01$ \\
Nodule structure $(\mathbf{n}, \%)$ & \\
Solid & $2,936(52.01 \%)$ \\
Cystic & $1,377(24.39 \%)$ \\
Mixed & $1,332(23.59 \%)$ \\
Mean nodule size $(\mathrm{cm})$ & $1.31 \pm 0.56$ \\
TSH value (mean \pm SD) $\mathrm{mIU} / \mathrm{L}$ & $2.87 \pm 0.45$ \\
Free T3 value (mean $\pm \mathrm{SD}) \mathrm{pg} / \mathrm{mL}$ & $3.76 \pm 0.87$ \\
Free T4 value (mean $\pm \mathrm{SD}) \mathrm{pg} / \mathrm{mL}$ & $1.23 \pm 0.24$ \\
TIRADS classification $(\mathbf{n}, \%)$ & \\
TIRADS 2 & $1,916(33.94 \%)$ \\
TIRADS 3 & $3,273(57.98 \%)$ \\
TIRADS 4a & $234(4.31 \%)$ \\
TIRADS 4b & $114(2.01 \%)$ \\
TIRADS 4c & $72(1.27 \%)$ \\
TIRADS 5 & $36(0.63 \%)$ \\
\hline &
\end{tabular}

TSH: Thyroid-stimulating hormone, SD: Standard deviation, BMI: Body mass index, TIRADS: Thyroid imaging reporting and data system treatment was used in $36 \%$ of the patients after surgery. When the tumor diameters were evaluated according to cancer types, the mean tumor diameters in PTC, FTC and MTC were $0.9 \pm 0.12 \mathrm{~mm}, 1.7 \pm 0.41 \mathrm{~mm}$, and $1.1 \pm 0.12 \mathrm{~mm}$, respectively.

When the relationship between the demographic and other characteristics of the patients with nodules and the risk of thyroid cancer was evaluated, thyroid cancer risk had no relationship with the TSH, fT3 and fT4 values and age but was found to be related to BMI, gender, nodule structure and diameter, and TIRADS score (Table 4). A

Table 3. Characteristics of the patients that underwent a biopsy with incidentally detected thyroid nodules

\begin{tabular}{|c|c|}
\hline \multicolumn{2}{|l|}{ Variable } \\
\hline \multicolumn{2}{|c|}{ Patients with incidentally detected thyroid nodules $(n=5,645)$} \\
\hline Biopsy not recommended & $4,617(81.79 \%)$ \\
\hline Biopsy recommended & $514(9.10 \%)$ \\
\hline Biopsy performed & $392(6.94 \%)$ \\
\hline Biopsy not performed & $122(2.16 \%)$ \\
\hline \multicolumn{2}{|l|}{ Biopsy result $(n=392)$} \\
\hline Benign & 224 (57.14\%) \\
\hline Suspected malignancy & $100(25.51 \%)$ \\
\hline Malignant & $68(17.34 \%)$ \\
\hline \multicolumn{2}{|l|}{ Operation type $(n=142)$} \\
\hline Right total lobectomy & $24(16.90 \%)$ \\
\hline Left total lobectomy & $12(8.45 \%)$ \\
\hline Bilateral total thyroidectomy & $96(67.60 \%)$ \\
\hline $\begin{array}{l}\text { Bilateral total thyroidectomy + central neck } \\
\text { dissection }\end{array}$ & $10(7.04 \%)$ \\
\hline \multicolumn{2}{|l|}{ Histological type of tumor $(n=114)$} \\
\hline Papillary thyroid cancer & $72(63.15 \%)$ \\
\hline Follicular thyroid cancer & $39(34.21 \%)$ \\
\hline Medullary thyroid cancer & $3(2.63 \%)$ \\
\hline \multicolumn{2}{|l|}{ Gender in tumor presence $(n=114)$} \\
\hline Male & $46(40.35 \%)$ \\
\hline Female & $68(59.65 \%)$ \\
\hline \multicolumn{2}{|c|}{ Tumor diameter according to histological type (mean \pm SD) } \\
\hline Papillary thyroid cancer & $0.9 \pm 0.12 \mathrm{~cm}$ \\
\hline Follicular thyroid cancer & $1.7 \pm 0.41 \mathrm{~cm}$ \\
\hline Medullary thyroid cancer & $1.1 \pm 0.12 \mathrm{~cm}$ \\
\hline \multicolumn{2}{|l|}{ Lymph node metastasis } \\
\hline Present & $8(7.01 \%)$ \\
\hline Absent & $106(92.98 \%)$ \\
\hline \multicolumn{2}{|l|}{ RAl treatment } \\
\hline Present & $36(31.57 \%)$ \\
\hline Absent & $78(68.42 \%)$ \\
\hline
\end{tabular}

RAI: Radioactive iodine, SD: Standard deviation 
multinominal logistic regression analysis was applied to all variables found significant in the univariate analysis (backward stepwise method). According to the results, the risk of thyroid cancer was increased 1.7-fold by increased BMI (OR: 1.71, 95\% CI: 1.43-2.96), 1.8-fold by female gender (OR: 1.79, CI: 1.21-2.67), 1.6-fold by solid structure nodule type (OR: 1.62, CI: 1.27-8.54), 2.7-fold by increased nodule size (OR: 2.71, CI: 1.11-3.31), and 4.7-fold by increased TIRADS (OR: 4.73, CI: 1.76-7.31) (Table 5).

Table 4. Comparison of variables between the patients with benign thyroid nodules and those with thyroid cancer

\begin{tabular}{llll} 
Variable & Benign group & Cancer group & $\mathbf{p}$ \\
\hline Age $($ years $)$ & $34.52( \pm 2.44)$ & $36.57( \pm 2.84)$ & $\mathbf{0 . 3 9 6}$ \\
Gender $(\mathbf{n}, \%)$ & - & - & $\mathbf{0 . 0 3 7 ^ { * }}$ \\
Male & $2,605(46.93)$ & $46(40.35)$ & - \\
Female & $2,946(53.07)$ & $68(59.65)$ & - \\
BMI $\left(\mathrm{kg} / \mathrm{m}^{2}\right)$ & $26.4( \pm 1.5)$ & $29.6( \pm 2.3)$ & $\mathbf{0 . 0 3 4 ^ { * }}$ \\
Nodule structure & - & - & $\mathbf{0 . 0 2 1 ^ { * }}$ \\
(n, \%) & & & \\
Solid & $2,840(51.35)$ & $96(84.21)$ & - \\
Cystic & $1,377(24.89)$ & $0(0)$ & - \\
Mixed & $1,314(23.76)$ & $18(15.79)$ & - \\
Mean nodule size & $0.98( \pm 0.11)$ & $1.56( \pm 0.84)$ & $\mathbf{0 . 0 3 1 ^ { * }}$ \\
(mm) & & & \\
Mean TSH value & $2.52( \pm 0.24)$ & $2.91( \pm 0.36)$ & 0.342 \\
Mean T3 value & $3.81( \pm 0.45)$ & $3.65( \pm 0.29)$ & 0.714 \\
Mean T4 value & $1.52( \pm 0.24)$ & $1.19( \pm 0.049)$ & 0.374 \\
TIRADS classification & - & - & $\mathbf{0 . 0 1 7 *}$ \\
TIRADS 1-2 & $1.916(34.64)$ & $0(0)$ & - \\
TIRADS 3 & $3.269(59.10)$ & $4(3.51)$ & - \\
TIRADS 4 & $344(6.22)$ & $76(66.67)$ & - \\
TIRADS 5 & $2(0.003)$ & $34(29.82)$ & - \\
\hline TSH Thy & & & \\
\hline
\end{tabular}

TSH: Thyroid-stimulating hormone, SD: Standard deviation, BMI: Body mass index, TIRADS: Thyroid imaging reporting and data system, *Statistically significant at 0.05

Table 5. Multivariate logistic regression analysis of the presence of thyroid cancer (dependent: thyroid cancer; independent: investigated variables)

\begin{tabular}{lllll} 
& Exp (B) & $\mathbf{p}$ & OR & OR (95\% CI) \\
\hline Gender & 2,918 & $\mathbf{0 . 0 0 4 *}$ & 1.79 & $(1.21-2.67)$ \\
BMI & 2,312 & $\mathbf{0 . 0 0 4 *}$ & 1.71 & $(1.43-2.96)$ \\
$\begin{array}{l}\text { Nodule structure } \\
\text { (solid) }\end{array}$ & 1,189 & $\mathbf{0 . 0 3 5 *}$ & 1.62 & $(1.27-3.54)$ \\
Nodule size & 2,117 & $\mathbf{0 . 0 1 2 *}$ & 2.71 & $(1.11-3.31)$ \\
TIRADS staging & 2,745 & $\mathbf{0 . 0 0 2 *}$ & 4.73 & $(1.76-7.31)$ \\
\hline
\end{tabular}

*Statistically significant at 0.05 . Backward method, OR: Odds ratio, $\mathrm{Cl}$ :

Confidence interval, BMI: Body mass index, TIRADS: Thyroid imaging reporting and data system

\section{Discussion}

Check-up examinations, which have become increasingly important in the last decade, are among one of the most common reasons for adults to seek medical help (1). Diagnostic centers and hospitals offer various health check-up "packages" to meet this need (15). The purpose of a routine health check should be to identify risk factors and early signs of disease, as well as to prevent the development of future diseases with early intervention or to prevent the manifestation of diseases by changing risk factors (16). Furthermore, routine health checks are often comprehensive in their approach and involve the evaluation of multiple organ systems simultaneously to detect health problems. However, this non-specific method can sometimes cause more harm than good due to overdiagnosis, overtreatment, distress or injury caused by invasive follow-up tests, anxiety caused by false positive test results, false assurance due to false negative test results, and possible continuation of negative health behaviors.

Check-up "packages" include blood tests, electrocardiogram, echocardiogram, abdominal US and thyroid US scans. Among these, thyroid US is the gold standard in the diagnosis of thyroid nodules. Non-palpable nodules detected during US or other imaging methods are called "incidental nodules" or "incidentalomas". In fact, thyroid nodules are frequently encountered in clinical practice. It is known that the prevalence of thyroid nodules in the general population is $4-7 \%$ based on detection by palpation alone (4). On the other hand, with the development of modern diagnostic technology and the introduction of high-resolution US into clinical practice, there has been a significant increase in the detection of thyroid incidence in recent years. It should also be noted that the rate of thyroid nodule detection gradually has also increased with the wide use of US in check-up screening in healthy individuals. In this study, we determined the prevalence of thyroid US incidentaloma as $23.18 \%$ while the prevalence of thyroid cancer was $0.47 \%$. The clinical importance of detecting thyroid nodules by US is based on the need to exclude thyroid cancer, which is seen in $7-15 \%$ of cases depending on various factors (6). Of all the thyroid nodules detected in our study, $1.98 \%$ were malignant, which is consistent with the rates reported in the literature (5).

The main point to be discussed based on this study is that in research conducted in countries, such as the United States and South Korea, where cancer statistics are recorded without exception, there has been a significant increase in the incidence of thyroid cancer within the last 
three decades according to epidemiological information; however, thyroid cancer-related mortality has not increased during this period and remained at a constant rate of 0.5 per $100,000(8,17)$. Although we were not able to obtain the data on the long-term results and mortality of our patients since they presented to our hospital for a check-up examination and some were already being followed up in different health institutions, we consider that the general knowledge that the early diagnosis of cancer can be life-saving may not always be valid for thyroid cancer, and routine checkup controls may lead to the overdiagnosis of this cancer. On the other hand, in patients diagnosed early, surgical treatment is performed when the tumor is small and there is no capsule infiltration or lymph node metastasis; thus, there is less surgical morbidity, such as recurrent nerve injury and reduced need for radioactive iodine treatment.

In our report, although the demographic data were consistent with female dominance reported in previous studies, the female-male ratio was 1.14 in the presence of thyroid nodules and 1.47 in thyroid cancer, which are lower compared to the literature data (18-20). As a result of the multivariate logistic regression analysis performed by ignoring the difference between the rates of nodule detection between genders, we have demonstrated that the rate of thyroid cancer development in patients with nodules in the female gender is significantly higher compared to the male gender.

There was no significant difference in age between the patients with and without malignant nodules. Although many studies reported a higher incidence of malignancy in the elderly individuals (19), there are also researchers showing that malignant nodules are more common among patients aged $\leq 45$ years $(21,22)$. When we evaluated our data in terms of cancer types, PTC was the most common at a frequency of $63.15 \%$, followed by FTC at $34.21 \%$ and MTC at $2.63 \%$. The results in our study are consistent with the literature in terms of PTC being the most common among the differentiated thyroid cancers, and its predominance was also observed in all previous studies $(4,23,24)$. In our study, total thyroidectomy was performed in $67.60 \%$ of the cases, lobectomy in $25.35 \%$, and total thyroidectomy with central neck dissection in $7.04 \%$ (1.6\%).

The main radiological evaluation of thyroid nodules is always performed by US, and it is known that some sonographic findings are observed more frequently in malignant nodules. The sonographic size of the nodule is used as a basis for performing thyroid FNAB and determining the scope of the surgery to some extent. Whether the size of the thyroid nodule affects the risk of malignancy or the accuracy of thyroid FNAB remains controversial, but this parameter is often used in decision-making regarding surgical and medical treatment. Therefore, it is important to determine whether there is a relationship between nodule size and malignancy risk. In our study, a statistically significant difference was found between the size of the malignant and non-malignant nodules, and it was observed that the incidence of malignancy detection increased as the nodule diameter increased. However, there are conflicting findings in the literature concerning the relationship between nodule diameter and malignancy (25-28). Some authors suggested that nodule size was a reliable determinant of malignancy and reported a non-linear relationship between cancer risk and increased thyroid nodule size (25). Supporting this, another study showed that the risk of malignancy was higher in nodules of $2 \mathrm{~cm}$ or larger (26). In contrast, other studies suggested that the size of thyroid nodules was inversely related to the risk of malignancy, with lower rates of malignancy seen in larger nodules $(27,28)$.

It is also commonly accepted knowledge that solitary thyroid nodules have higher malignant potential than cystic nodules. Although a completely cystic nodule is rare $(<2 \%$ of all nodules), it is probably not malignant. In addition, the spongy appearance, which is defined as more than half of the nodule volume filled with multiple microcystic contents, indicates a benign thyroid nodule at a rate of $99.7 \%$ (4). In our study, when the variables of the patients with benign thyroid nodules and thyroid cancer were compared, a high significant statistical association was found between the solid structure of the nodule and thyroid cancer. However, the multivariate analysis revealed that the presence of solid nodules was not the only criterion for malignancy, and only when combined with ultrasonographic TIRADS staging, it showed a significant association for thyroid cancer.

In thyroid nodules, in addition to the size and/or solitary nature, the likelihood of cancer is higher if it presents with certain sonographic features, including higher hypoechogenicity compared to normal thyroid parenchyma, increased intranodular vascularity, irregular infiltrative borders, presence of microcalcification, absence of a halo, and the height of the nodule being greater than its transverse dimension (4). Except for suspected non-sensitive cervical lymphadenopathy that is specific for malignancy, no sonographic finding alone or in combination is sufficient to detect all malignant nodules. However, some features and their combination are of 
high predictive value for malignancy. Therefore, scorebased classifications are used, in which each sonographic suspicious finding is considered as a separate risk factor for malignancy and the risk of malignancy increases as the number of these findings increases in a nodule (23). In our study, it was shown that the risk of malignancy significantly increased in patients with TIRADS $4 \mathrm{c}$ and 5 nodules compared to the other TIRADS groups among the cases that were recommended a biopsy.

In our study, the mean TSH value of the patients with thyroid nodules was found to be $2.87 \pm 0.45$. It remains unclear whether TSH plays a role in the development or progression of this disease, or both. The results of many studies have supported the association between high TSH levels and the risk of thyroid cancer in nodular thyroid disease (29). However, in our study, when the variables of the patients with benign thyroid nodules and those with thyroid cancer were compared, no statistically significant relationship was found between the TSH value and thyroid cancer.

It is well known that increased BMI constitutes a risk factor for different types of cancer (30). In addition, there are different studies showing a positive relationship between thyroid cancer and BMI (31-33). In our study, the mean BMI of the patients detected to have thyroid nodules during the check-up examination was calculated to be $27.56 \pm 2.01$. There was also a statistically significant relationship between BMI and thyroid cancer, and the thyroid cancer risk was observed to increase with the increase in BMI. These results were similar to the data in the literature.

\section{Study Limitations}

Our study has certain limitations and strengths. The most important limitation is the retrospective design and that not all patients recommended a biopsy underwent this procedure. However, it is useful to note that almost all patients with a high thyroid cancer risk according to TIRADS staging (TIRADS $4 \mathrm{~b}, 4 \mathrm{c}, 5$ ) were biopsied. The patient group in which a biopsy could not be performed was the TIRADS 4a group, and the risk of malignancy in this group of patients is around $3 \%$ according to our review of the literature. In addition, the most important aspect of this study is that it included the highest number of checkup patients that were incidentally detected to have thyroid nodules. All patients were ultrasonographically examined by expert radiologists, and TIRADS staging was used as standard in all cases.

\section{Conclusion}

The main difficulty in evaluating and managing thyroid nodules is to avoid the inappropriate overuse of thyroid US, thyroid FNAB and surgery while trying to identify clinically significant malignant nodules. In doing so, although clinical studies have provided strong evidence on screening methods to clarify international guidelines, hard data on the benefits and harm of various screening tests are still lacking, and the role of check-up examinations and thyroid cancer screening in the general population remains controversial. Regarding the diagnosis of thyroid cancer through a checkup examination, the data obtained as a result of more detailed studies should be evaluated and the increased incidence of thyroid cancer in the last three years may not only be as a result of overdiagnosis but also due to a real increase in incidence caused potentially modifiable factors, such as radiation exposure, iodine intake, and lifestyle. However, considering that early diagnosis of thyroid cancer without lymph node involvement can reduce both surgical complications and prevent the risks of radioactive iodine treatment, it is concluded that thyroid cancer being detected at an early stage constitutes an important advantage for the healthy population undergoing a check-up.

\section{Ethics}

Ethics Committee Approval: The study was approved by the Ethics Committee of Medipol University (10840098604.01.01-E.17833 number: 535).

Informed Consent: Due to the retrospective nature of the study, we did not seek informed consent.

Peer-review: Externally peer-reviewed.

\section{Authorship Contributions}

Concept: D.A., Design: D.A., P.B., Data Collection or Processing: D.A., P.B., Analysis or Interpretation: P.B., Literature Search: D.A., Writing: D.A.

Conflict of Interest: No conflict of interest was declared by the authors.

Financial Disclosure: The authors declared that this study has received no financial support.

\section{References}

1. Mehrotra A, Zaslavsky AM, Ayanian JZ. Preventive health examinations and preventive gynecological examinations in the United States. Arch Intern Med 2007;167(17):1876-1883.

2. Sox HC. The health checkup: Was it ever effective? Could it be effective? JAMA 2013;309(23):2496-2497. 
3. Song CY, Shen Y, Lu YQ. Role of routine check-up in the prognosis of patients with pancreatic cancer: A puzzling phenomenon. Hepatobiliary Pancreat Dis Int 2021;20(1):67-73.

4. Haugen BR, Alexander EK, Bible KC, Doherty GM, Mandel SJ, Nikiforov YE, et al. 2015 American Thyroid Association Management Guidelines for Adult Patients with Thyroid Nodules and Differentiated Thyroid Cancer: The American Thyroid Association Guidelines Task Force on Thyroid Nodules and Differentiated Thyroid Cancer. Thyroid 2016;26(1):1-133.

5. Guth S, Theune U, Aberle J, Galach A, Bamberger CM. Very high prevalence of thyroid nodules detected by high frequency $(13 \mathrm{MHz})$ ultrasound examination. Eur J Clin Invest 2009;39(8):699-706.

6. Hegedus L. Clinical practice. The thyroid nodule. N Engl J Med 2004;351(17):1764-1771.

7. Siegel RL, Miller KD, Jemal A. Cancer statistics, 2020. CA Cancer J Clin 2020;70(1):7-30.

8. Davies L, Welch HG. Current thyroid cancer trends in the United States. JAMA Otolaryngol Head Neck Surg 2014;140(4):317-322.

9. Leenhardt L, Bernier MO, Boin-Pineau MH, Conte DB, Maréchaud R, Niccoli-Sire P, et al. Advances in diagnostic practices affect thyroid cancer incidence in France. Eur J Endocrinol 2004;150(2):133-139.

10. Brito JP, Al Nofal A, Montori V, Hay ID, Morris JC. The impact of subclinical disease and mechanism of detection on the rise in thyroid cancer incidence: a population-based study in Olmsted County, Minnesota during 1935 through 2012. Thyroid 2015;25(9):999-1007.

11. Singh Ospina N, Iñiguez-Ariza NM, Castro MR. Thyroid nodules: diagnostic evaluation based on thyroid cancer risk assessment. BMJ 2020;368:16670.

12. Cooper DS, Doherty GM, Haugen BR, Kloos RT, Lee SL, Mandel SJ, et al. Revised American Thyroid Association management guidelines for patients with thyroid nodules and differentiated thyroid cancer. Thyroid 2009;19(11):1167-1214.

13. Gharib H, Papini E, Garber JR, Duick DS, Harrell RM, Hegedüs L, et al. AACE/ACE/AME Task Force on Thyroid Nodules. American Association of Clinical Endocrinologists and Associazione Medici Endocrinologi medical guidelines for clinical practice for the diagnosis and management of thyroid nodules--2016 Update. Endocr Pract 2016;22(5):622-639.

14. Jameson JL, De Groot JL. Endocrinology adult and pediatric. In: Thyroid Neoplasia, Pacini F, Marchisotta S, De Groot JL (editors). 6th ed., Philadelphia: Saunders Elsevier, 2010:1668-1701.

15. Krogsbøll LT, Jørgensen KJ, Grønhøj Larsen C, Gøtzsche PC. General health checks in adults for reducing morbidity and mortality from disease: cochrane systematic review and meta-analysis. BMJ 2012;345:e7191. doi: 10.1136/bmj.e7191.

16. Gøtzsche PC, Jørgensen KJ, Krogsbøll LT. General health checks don't work. BMJ 2014;348:g3680. doi: 10.1136/bmj.g3680.

17. Ahn HS, Kim HJ, Welch HG. Korea's thyroid-cancer "epidemic"screening and overdiagnosis. N Engl J Med 2014;371(19):17651767.

18. Roman BR, Morris LG, Davies L. The thyroid cancer epidemic, 2017 perspective. Curr Opin Endocrinol Diabetes Obes 2017;24(5):332336.

19. Figge JJ. Epidemiology of thyroid cancer. In Thyroid Cancer: A Comprehensive Guide to Clinical Management. 2nd ed., New York: Springer, 2006:9-13.
20. Preston-Martin S, Franceschi S, Ron E, Negri E. Thyroid cancer pooled analysis from 14 case-control studies: What have we learned? Cancer Causes Control 2003;14(8):787-789.

21. Rago T, Fiore E, Scutari M, Santini F, Di Coscio G, Romani R, et al. Male sex, single nodularity, and young age are associated with the risk of finding a papillary thyroid cancer on fine-needle aspiration cytology in a large series of patients with nodular thyroid disease. Eur J Endocrinol 2010;162(4):763-770.

22. Bessey LJ, Lai NB, Coorough NE, Chen H, Sippel RS. The incidence of thyroid cancer by fine needle aspiration varies by age and gender. J Surg Res 2013;184(2):761-765.

23. Kwak JY, Han KH, Yoon JH, Moon HJ, Son EJ, Park SH, et al. Thyroid imaging reporting and data system for US features of nodules: A step in establishing better stratification of cancer risk. Radiology 2011;260(3):892-899.

24. Chow SM, Law SC, Au SK, Leung TW, Chan PT, Mendenhall WM, et al. Differentiated thyroid carcinoma: comparison between papillary and follicular carcinoma in a single institute. Head Neck 2002;24(7):670-677.

25. Kamran SC, Marqusee E, Kim MI, Frates MC, Ritner J, Peters H, et al. Thyroid nodule size and prediction of cancer. J Clin Endocrinol Metab 2013;98(2):564-570.

26. Raparia K, Min SK, Mody DR, Anton R, Amrikachi M. Clinical outcomes for "suspicious" category in thyroid fine-needle aspiration biopsy: patient's sex and nodule size are possible predictors of malignancy. Arch Pathol Lab Med 2009;133(5):787790 .

27. Cavallo A, Johnson DN, White MG, Siddiqui S, Antic T, Mathew M, et al. Thyroid nodule size at ultrasound as a predictor of malignancy and final pathologic size. Thyroid 2017;27(5):641-650.

28. Frates MC, Benson CB, Doubilet PM, Kunreuther E, Contreras M, Cibas ES, et al. Prevalence and distribution of carcinoma in patients with solitary and multiple thyroid nodules on sonography. J Clin Endocrinol Metab 2006;91(9):3411-3417.

29. Zafón C, Obiols G, Mesa J. Preoperative TSH level and risk of thyroid cancer in patients with nodular thyroid disease: Nodule size contribution. Endocrinol Nutr 2015;62(1):24-28.

30. Pischon T, Nimptsch K. Obesity and risk of cancer: an introductory overview. Recent Results Cancer Res 2016;208:1-15.

31. Han JM, Kim TY, Jeon MJ, Yim JH, Kim WG, Song DE, et al. Obesity is a risk factor for thyroid cancer in a large, ultrasonographically screened population. Eur J Endocrinol 2013;168(6)879-886.

32. Oh SW, Yoon YS, Shin SA. Effects of excess weight on cancer incidences depending on cancer sites and histologic findings among men: Korea National Health Insurance Corporation Study. J Clin Oncol 2005;23(21):4742-4754.

33. Rinaldi S, Lise M, Clavel-Chapelon F, Boutron-Ruault MC, Guillas G, Overvad K, et al. Body size and risk of differentiated thyroid carcinomas: findings from the EPIC study. Int J Cancer 2012;131(6):E1004-E10014. doi: 10.1002/ijc.27601 